\title{
Embodying Exoticism: Gendered Nuances of Swedish Hyper-Whiteness in the United States
}

Catrin Lundström

The self-archived postprint version of this journal article is available at Linköping University Institutional Repository (DiVA):

http:/ / urn.kb.se/ resolve?urn=urn:nbn:se:liu:diva- 142459

N.B.: When citing this work, cite the original publication.

Lundström, C., (2017), Embodying Exoticism: Gendered Nuances of Swedish Hyper-Whiteness in the United States, Scandinavian Studies, 89(2), 179-199. https:// doi.org/ 10.5406/ scanstud.89.2.0179

Original publication available at:

https:/ / doi.org/ 10.5406/ scanstud.89.2.0179

Copyright: University of Illinois Press

https:// www.press.uillinois.edu/ 


\section{Embodying exoticism:}

\section{Gendered nuances of Swedish hyper-whiteness in the US}

\section{Catrin Lundström}

\section{Scandinavian Studies}

Vol. 89, No. 2, Nordic Whiteness (Summer 2017), pp. 179-199

Published by: University of Illinois Press on behalf of the Society for the Advancement of Scandinavian Study

DOI: 10.5406/scanstud.89.2.0179

https://www.jstor.org/stable/10.5406/scanstud.89.2.0179

Page Count: 21

\section{Corresponding author:}

Catrin Lundström

REMESO Institute for Research on Migration, Ethnicity and Society

Linköping University

60174 Norrköping, Sweden

catrin.lundstrom@liu.se

Tel +46-11-363435

\section{Bio:}

Catrin Lundström is Associate Professor in Sociology and LiU Research Fellow at REMESO Institute for Research on Migration, Ethnicity and Society at Linköping University in Sweden. Lundström's research examines the intersections of gender, Swedishness and whiteness through a transnational lense. Her books include Swedish Latinas: Race, Class and Gender in the Geography of Swedishness and White Migration: Gender Whiteness and Privilege in Transnational Migration. Lundström is the author of several international articles in the fields of ethnographic research, migration studies, critical race and whiteness studies, and feminist sociology, published in Social Identities, Gender, Place and Culture, Journal of Intercultural Studies and NORA: Nordic Journal of Feminist and Gender Studies, etc. She regularly analyses these topics in Swedish and Nordic media and public debates. She was also a visiting scholar at the University of Arizona, Tucson, and University of California, Santa Barbara. 


\title{
Embodying exoticism:
}

\section{Gendered nuances of Swedish hyper-whiteness in the US}

\begin{abstract}
Nordic whiteness has a privileged place in the history of race, reflected in constructions of white Swedish femininity as the embodiment of beauty and purity. This article examines Swedish migrant women's gender and nation-specific experiences of Nordic whiteness when moving from a dominant discourse of colour-blindness in Sweden to overt racial privilege in southwestern United States. As the women altered from being professionals to upper-middleclass homemakers or stay-at-home mothers, their gendered and classed experiences of whiteness involved a shift in their experiences of 'being white'. The study is based on a year of ethnographic work in a network for Swedish women living abroad, including in-depth interviews with 33 migrant women and three of their husbands, all of whom move to the US from the 1940s onwards. Migration from Sweden to the United States involved a transition from white normativity to exotic Swedishness, including the embodiment of a kind of hyperwhiteness linked to the history of the Nordic race in the US. The article takes an empirical view of the contemporary embodiment of Swedish hyper-whiteness in the United States and analyses its historical traces from a critical whiteness studies perspective.
\end{abstract}

Keywords: Nordic whiteness, gender, migration, United States. 


\section{Embodying exoticism:}

\section{Gendered nuances of Swedish hyper-whiteness in the US}

Just the fact that you are Swedish - or rather a Swedish woman - makes you very interesting. When I go shopping, I always hear: “Oh what's that accent, where are you from?” They are so interested. Sweden is so interesting. Sweden has a very good image in the world.

(Lise-Lotte, 55, residing in the US for 20 years)

Being Swedish in the US represents a particular version of whiteness that is related to the history of the Nordic race (Lunde 2010). The idea of a superior Nordic whiteness, or 'race Nordique', has been a persistent phenomenon associated with racial purity and homogeneity (Garner 2015). In the modern era, the term "Nordic" is used to designate "a superior race" reflecting the racial standard: tall, blue-eyed and, if a woman, blonde (Painter 2010, 305). Pure Nordics are described as having fair skin and as being white par excellence, who have "not only given the world civilization, enterprise, and bravery; they also possess heavenly beauty: the gods of lovely ancient Greece were, of course, blond” (Painter 2010, 309). It is perhaps the echo of these racial layers that makes being Swedish, "or rather a Swedish woman" in the US, “interesting”. 1

This article follows some of the transnational 'traces' of Swedish whiteness that emerged in interviews with Swedish women who had migrated to the US and encountered a version of whiteness that was very different to that they had experienced in Sweden. The history of racial purity and privilege for Nordic migrants makes the white position tangible for these 
women when moving from a dominant discourse of colour-blindness in Sweden. The women, who migrated to the US from the 1940s onwards, are ascribed historical and contemporary images of Nordic whiteness and Swedish femininity, thus making them symbolic bearers of the racialised boundaries of the nation and its 'national qualities'.

In her book, The History of White People, Nell Irvin Painter points to the racialised aspects of migration and the feasibility of Nordic immigrants integrating into the US melting pot at a time when non-Nordic immigrants in a similar situation are doomed to “absolute failure” (Painter 2010, 307). This article argues that the lingering idea of certain characteristics, coupled with the Nordic race as the embodiment of purity or beauty, is still true for these contemporary migrants from Sweden. This is also a gendered experience, in that the women are ascribed certain notions of Swedish (or Nordic) hyper-whiteness that are attached to standards of racial purity, extraordinary beauty and sexual liberation. Consequently, their accentuated whiteness implicates re-configurations of femininity and respectability, including aspects of sexuality and morality.

\section{Transnational whiteness}

The editors of the collection Transnational Whiteness Matters, Aileen Moreton-Robinson, Maryrose Casey and Fiona Nicoll (2008), point out that whiteness as an imperial project has undergone several changes over the centuries and across geographies. This article explores the social and cultural boundaries of a 'particular' whiteness - Swedish whiteness - as it travels and assumes a 'new' shape in a different context. The aim of the article is to unpack the layers of whiteness that are tied to Swedishness and to particular ideas about the Nordic race as they are experienced by Swedish migrant women in the US. 
The idea of 'an ideal whiteness' points to an internal hierarchy within the category of whiteness (Lunde 2010; Garner 2015). In this context, Swedes still tend to be identified and thought of as the purest people of the white race, representing a kind of hyper-whiteness (Hübinette and Lundström 2014; cf. Roediger 1991). In fact, in Carl C. Brigham’s estimate of the proportions of blood stock from different European countries in the US in 1923, Swedes are classified as the whitest of all (white), because they were thought to be the only race in Europe to have 100 per cent Nordic blood (Brigham 1923, 159).

Hence, whitenesses can be similar yet different (such as Swedish or Polish whiteness). Pursuing Swedish whiteness in the US implies that whiteness is not a national construct, but intersects with a globalised history of race. From her study of transnational representations of white femininity, Raka Shome observes that it is crucial to link national constructions of whiteness to a transnational frame:

Given that whiteness is a contextual formation, and that national contexts today are shaped by, as well as shaping, transnational relations of power, ignoring transnational linkages in the production of whiteness is limiting, for it can potentially perpetuate a view that power relations of whiteness within the nation are somehow disconnected from larger transnational struggles and flows [...]. Examining whiteness through the methodological lens of the transnational also enables us to avoid conceiving whiteness as though its logics are the same wherever and whenever. A transnational contextual analysis of whiteness recognizes that the power of whiteness lies precisely in its ability to constantly shift its strategies of reproduction in response to the changing contours of the nation, and that those 
contours are always imbricated in larger international and geopolitical relations. (Shome, 2011, p. 404)

Seeing whiteness as both a national and transnational construct can help us to identify the diverse expressions and effects of whiteness and their complex intersections with other axes of inequality produced through national and transnational linkages. As Ruth Frankenberg argues, whiteness:

is a complexly constructed product of local, regional, national and global relations, past and present. Thus the range of possible ways of living whiteness, for an individual white woman in a particular time and place, is delimited by the relations of racism at that moment and in that place. (Frankenberg, 1993, 236)

By re-contextualiszing Swedish whiteness, whiteness appears as a social, material and symbolic construction that is embodied, lived and experienced differently. At the same time, it is regarded as a normative structure in which white normativity and normalcy reproduce themselves. A critical whiteness studies perspective on migration focuses on how whiteness constitutes a form of privilege that is reinstalled and sometimes even reinforced through migration, instead of departing from the invisible claim of whiteness or the idea of the non-problematic white migrant (Lundström 2014). Such an analysis raises questions like: How do white migrant women live and experience whiteness when they move from the social, racial and political landscape of Sweden to the United States? What kinds of (dis-)identification take shape as Swedish women migrate across national and racial formations? 


\section{White capital}

America is such a crazy country. It is almost impossible to fail. (Ebba, 43, living in California for 5 years)

Whiteness as a form of capital can be changed into other kinds of capital, including social or economic capital (Garner 2007; Lundström 2014; Skeggs 1997). ${ }^{2}$ The specific migratory experiences of the Swedish women I interviewed are here used to analyse how gender- and nation-specific forms of white capital are upheld, converted or challenged through migration. They are also used to probe how embodied privilege travels and is re-installed in different contexts. The concept of white capital builds on Pierre Bourdieu's (1986) forms of capital (social, economic, cultural and symbolic) and is here employed as a form of embodied and institutionalised cultural capital that can be converted into other forms of capital across social space (thus distinguishing capital from resources). Cultural capital appears in three states embodied, institutionalised and objectified - and can under certain circumstances be institutionalised in different forms (Bourdieu 1986). As a site of the materialisation of taste, the body becomes a carrier of markers of class, in which discourses of femininity, masculinity and whiteness are also embodied (Skeggs 1997). However, as Beverley Skeggs argues,

[g]ender, class and race are not capitals as such, rather they provide the relations in which capitals come to be organized and valued. Masculinity and Whiteness, for instance, are valued (and normalized) forms of capital. Our social locations 
influence our movement and relation to other social positions and hence our ability to capitalize further on the assets we already have. (Skeggs, 1997, p. 9)

In terms of whiteness, Steve Garner $(2007,59)$ advocates that cultural capital involves “a belief that one is part of a tradition of dominance including Empire, knowledge of norms and behaviour patterns that will produce intended outcomes in particular situations”. Such a view certainly shapes white migrants' notions of mobility rights, orientations and opportunities. At an individual level, whiteness as cultural capital is perhaps best captured in the concept of habitus, which includes bodily comportment and speaking as markers of distinction. The English language has been identified as such a form of cultural capital (Lan 2011). However, as the opening quote shows, a Swedish accent could be an auditory marker of a separate whiteness when it is recognised as Swedish. Hence, alongside the physically visual characteristics of whiteness - such as blonde hair, height, ivory skin and blue eyes - an identified Swedish accent can become a kind of cultural capital that intensifies the racial purity of the 'real Swede', albeit not only associated with positive characteristics. As Arne Lunde notices, Scandinavian accents on film were seen "as exotic at best, and unassimilated, strange, even ridiculous at worst” (cf. Lunde 2010, 12).

According to Skeggs (2004)), habitus as embodied cultural capital is an integral part of the person and, unlike other forms of cultural capital, can therefore not be transmitted by gifts, purchases or exchanges. In line with this reasoning, Sara Ahmed (2007) argues that whiteness is a form of habit; a second nature that defines what bodies do, how practices are repeated and shapes what bodies can do. Studying whiteness as embodied capital is somewhat paradoxical, given that whiteness is often associated with the state of disembodiment, invisibility, normalcy and universalism (Dyer 1997). Nonetheless, the cultural capital of 
whiteness has been institutionalised in many ways, including locally and globally, thereby providing some bodies with spaces to be "at home” (Ahmed 2000). Depending on how these resources are accumulated in bodies, and how they are carried out in social space, bodies carry unequal cultural baggage (Skeggs, 2004, 17). For this reason, white privilege has been described as "an invisible weightless knapsack” by Peggy McIntosh (2003). Embodied white capital can therefore travel with people and be linked to and upheld by (transnational) institutions, citizenships, a white (western) habitus and other resources that are transferrable (but mediated differently) cross-nationally (Weiss 2005).

Even though whiteness works as a form of privilege, privileges are seldom experienced as such (Kimmel 2003). In fact, 'not being aware of privilege is an important aspect of privilege' (Pease, 2010, 9). White privileges are often normalised and invisible to the people who embody them. Uninterrupted mobility is one element of white privilege. For the women in this study, migration was relatively easy in terms of control, choice, possibilities and admission - as Ebba's quote shows - in strong contrast to the migration of political refugees or undocumented migrants, whose mobility is constrained by money, borders, citizenship and/or juridical processes.

\section{White femininity}

For the women in the study, gender and whiteness intersect in complex ways and include aspects of racial and class privilege and gendered vulnerabilities. As the women often experienced increased economic dependence on their husbands after moving from Sweden, they had to negotiate racial and class privileges from a position that involves gendered inequality and social insecurity. This is where some of the complexities of white capital arise. Although white capital can be transferred and converted into new forms of capital, it also intersects with 
other axes of power, such as gender and class, which means that the boundaries of these categories are drawn in the local contexts (Skeggs 1997; Twine 2010). An intersectional perspective foregrounds the tensions and contradictions that the category of whiteness entails (Frankenberg, 1993). White privilege may change as groups locate in relation to structural advantages and disadvantages, which means that privileges take shape in relation to gendered and heterosexual norms, dependencies and regulations (Pease 2010; Johnson 2001).

Cultural constructions of femininity can convert whiteness - as the very definition of disembodiment - into an embodied phenomenon (Moon 1999). As a gendered embodied phenomenon, whiteness as cultural capital is intimately linked to the construction of femininity and respectability, including norms and regulations pertaining to heterosexual beauty, morality, body ideals and physical traits (often leading to age and weight concerns) as well as gendered forms of socialising, planning activities and maintaining social bonds and boundaries on behalf of the entire family. According to the women in this study, the appearance of a tall blonde woman in the US was associated with a particular gendered (and racialised) repertoire of experiences, such as sexual liberation or even exoticism. In response to the distinctive notions of Swedish whiteness, the women either dye their already blonde hair even lighter, or repudiate the stereotypical version of Swedish femininity.

Skeggs (2004) argues that femininity poses interesting problems for Bourdieu, because in the same way as masculinity, respectable (white) middle-class heterosexual femininities can be symbolically legitimate while not being symbolically dominant. In contrast to masculinity, femininity is a form of regulation rather than domination, although it can be useful in a local symbolic exchange, such as marriage. Consequently, femininity poses particular problems for whiteness and privilege, because these are inherently linked to heterosexual gender regimes and racialised hierarchies that influence the ways in which these women negotiate migration, family relations and respectability. 


\section{Examining contemporary Swedish migration in the US}

This research is based on a year of ethnographic work and in-depth interviews with 33 migrant Swedish women and three of their husbands (two Swedish and one US American) individually and in focus group discussions in the southwestern part of the US. The women are members of a network for Swedish women abroad called SWEA (Swedish Women's Educational Association). Longer term participant observations were conducted in two local SWEA chapters and included group discussions with members, attendance at lunches, dinner parties, high tea parties, Christmas fairs, informal and formal meetings and cultural events on a weekly to monthly basis. The participants, aged between 29 and 81 years (average age 53 years) had left Sweden at different periods in their lives from the 1940s to the early 21st century. The women presented themselves as white and heterosexual and the majority had middle- or upperclass backgrounds, with an income ranging from $\$ 100,000$ and upwards. ${ }^{3}$ Thus, they constitute a privileged migrant group that does not represent Swedish migration at large.

The majority - nineteen women - were married to men born and bred in the US. Six were married to Swedish men working for international corporations, five are divorced and/or single and two are widows. Two thirds of the women, including those who had left their careers in Sweden, became homemakers as a direct result of moving to the United States, or at the time of the interviews were 'stay-at-home-mums'. The women who were currently active in the working market either had their own businesses, were employed (in some cases by their spouses) or were working students. Most of the women, although not all, had other Swedish women as their closest friends. All the women except four had children.

The women are representative of Swedish emigrants in the sense that the USA is the country where most Swedish born emigrants live. Between approximately 55,000 and 
100,000 Swedish-born migrants live in the US and about 2,000 Swedish citizens (born in Sweden) migrate to the US every year, most of them (58 per cent) women (Eriksson 2008). Sweden has a long and interrelated history with the US due to the former Swedish and European colonisation and settler migration and the large emigration that took place in the $19^{\text {th }}$ century. ${ }^{4}$ The women's own migration is not necessarily a result of direct family relations, but denotes the extensive Swedish history of migration to the US. Between 1850 and 1930, about a quarter of Sweden's population - 1.3 million people - migrated to the United States, thereby contributing to a large community of Swedish-Americans. Today, over four million Americans identify as Swedish-American (Blanck 2006).

Like most women migrating to the US in the first migration wave, the women in this study were unmarried at the time of migration. At that time the desire to return home was much lower among women than men (Beijbom 2006). For women moving to Chicago, New York or Minneapolis in the late 1800s and early 1900s, migration was coupled with liberty and dignity, in contrast to the poor life and existence that dominated the Swedish countryside (Matović 1997). Domestic work in a white American middle-class household was a common employment for Swedish women migrating during that period; something that gave rise to American gendered ethnic stereotypes of "the Swedish maid”. ${ }^{5}$ In 1900, over 65 per cent of working age Swedish-born women were employed in domestic service. This kind of work was readily available, because there was no competition from native-born white American women (Lintelman 1991). This changed for second generation Swedes, because by then young Americans of Swedish heritage had become part of a white majority in America (Waters 1990). This reflects a history of upward class mobility that resonates with the contemporary migration investigated here. At the same time, in line with the development of social democracy's prosperous and liberal Swedish society, representations of Swedish femininity changed from that of "the Swedish maid" to the sexually liberated woman. 


\section{From wilful colour-blindness to overt racial privilege}

The history of race in Sweden is full of contradictions. At the beginning of the $20^{\text {th }}$ century, Sweden was in the frontline of racial biology. A number of biopolitical reforms were introduced to protect the Swedish nation from social degeneracy and proletarianisation, race mixture and immigration, continuous mass emigration to the US and other overseas European colonies and a decreasing birth rate among the middle- and upper classes. In 1922, the first academic institute in the world to study eugenics and human genetics - the State Institute for Racial Biology at Uppsala University - was founded with the full support of all the political parties represented in the Swedish Parliament. During the first half of the 1900s, due to the successful lobbying by race biologists and with the backing of the Social Democratic party, several laws and regulations were passed and enforced with the purpose of creating and upholding a perceived uniquely pure and valuable white nation. These included an anti-contraceptive law, a restrictive abortion law, an adoption law characterised by strong genetic thinking, a marriage law restricting those with inherited diseases and disabilities to marry, a restrictive immigration law which became even stricter before World War II to stop Jewish and other refugees from entering the country, the introduction of race biology in school and in the army and, above all, a sterilisation law that aimed to prevent the reproduction of the lower classes and biologically and socially exterminate the "inferior" and simultaneously increase the birth rate among the “fitted” and “better stocked” (Gustafsso 1996; Hirdman 1989; Johannisson 1991).

From the 1970s and onwards, Sweden turned away from the overt scientific racism that had dominated the first half of the century and instead converted itself ideologically into a multicultural nation of wilful colour-blindness, in the sense that race as a concept and as a category was abolished at the governmental and official level and in academia. Race is still 
considered to be irrelevant and obsolete in the contemporary Swedish context, mainly because human rights, democracy, social justice and antiracism are regarded as having been achieved. According to a Swedish logic, talking about race would hamper this development (Hübinette and Lundström 2014).

At first glance, the transformation from believing in and cultivating one of the most racialised and homogenising nation-building projects in the democratic world to elevating antiracism and multiculturalism as leading guiding principles may appear contradictory and paradoxical. However, it is precisely the enormously successful left-liberal nation-building and nation branding project of constructing and promoting "good Swedes" and "good Sweden" as the most tolerant and progressive of all white nations that makes it possible to claim that this was also a shift from one regime of hegemonic whiteness to another, guided by white antiracism (Hübinette \& Lundström 2014). The uninterrupted history of white governmentality is perhaps most overt in the lingering interconnection between Swedishness and whiteness - a deep national construct with similarities in the neighbouring Nordic countries (Loftsdóttir and Jenssen 2012).

Another central aspect of the construction of “good Sweden” is the country's achievements in gender equality policies and practices, linked to its generous welfare state and best epitomised and immortalised in the figure of the liberated and independent professional woman and "working mother" in a dual-earner household model (Borchorst and Siim, 2008). Sweden has therefore come to be regarded as exceptionally "woman-friendly". Along with other Nordic countries, it is ranked as one of the most gender-equal societies in the world. In the early 1970s, gender equality became firmly established in Sweden through the introduction of a series of progressive laws and regulations. During this phase, Swedish society, with its social democratic polices, moved from a housewife contract in which women were economically dependent on their husbands, to a gender-equality contract where women made 
a massive entry into the labour market and housewifely duties were taken over by strong public institutions (Hirdman 1989). In the US, the women's position often shifted from a dual-earner household model to one of a home-maker with men as breadwinners of the family.

Although gender equality policies have been successful in an international context, the state-sanctioned and institutionalised gender equality discourse has also been criticised for carrying with it a sense of national identity that is intimately intertwined with whiteness and for the exclusion of non-western, non-Christian migrants of colour from the very notion of gender equality, who are instead imagined and marked as inherently patriarchal (Keskinen et al. 2009). As we shall see later in the article, the contemporary narratives of Swedish whiteness reflect the history of race eugenics, gender equality and colour-blindness.

\section{Swedishness as white capital}

For the women I interviewed, migration to the US was a gendered and class experience, which was mediated through transnational ideas of Swedish femininity that provided a particular kind of white capital and a local exchange value that could be converted into profitable marriages. This facilitated an individual upward class mobility, mainly through marriage or employment. Marie, aged 36, who is married to a US American and has lived in the US for 16 years, explains that:

Everybody thinks that Swedish girls are so exotic. You have an advantage when they hear that you are Swedish. [...] When I applied for my first job they said: “Oh you are Swedish!” So I think that helped a bit. But most of all it helps to attract guys, I have to say. But even now when you are older, I think people feel they have 
something to talk with you about. You're a bit exotic compared with the Americans who grew up here.

Marie was 19 when she visited the US for the first time in the 1990s. She had just finished secondary school and went to the US to work for a year as an au-pair. For Marie, like most of the women in the study, the encounter with the United States was very positive. She perceived Americans as "welcoming”, "friendly”, "curious” and "interested” in her life story and Swedish origin, and as "more positive compared to other nationalities". Coming from a lower middleclass family background, living an ordinary life in a medium-size town in Sweden, Marie felt "attractive” and even "exotic" as a Swedish woman in the US. Being Swedish was, as she put it, “an advantage” when searching for a job or partner. Shortly after arriving in the US she met a wealthy man and married him. Today, Marie and her husband live in a large house in a wellto-do area on the Californian coast. Money is no longer a problem for her and she can invite her parents to visit them at least once a year. Marie describes her current life and class position as significantly different from her parents' “ordinary lives” in Sweden as a sheet-metal worker and a school cook.

Marie's story illustrates the potential of using Swedish femininity in ways that improve and strengthen a person's social position, albeit with distinct gendered outcomes, such as being "a bit exotic”. Her Swedish femininity proved to be an advantage when she applied for her first job, and, as she points out, was most helpful as a resource for heterosexual coupling. By converting her nation-specific version of white femininity into social and economic capital through marriage and work, she has been able to climb a rung on the transnational social structural ladder (like the earlier migrants before her had done). Upward class mobility through marriage seems to be easier for a Swedish woman in the US than for her counterpart in Sweden, 
because it requires an assessment of the positive racial and gender stereotyping of Swedish femininity. In Skeggs' (2004) words, the Swedish version of white femininity constitutes a form of cultural capital that is acknowledged and legitimised as high capital in the US.

\section{"I felt more like a woman"}

Being a white Swedish migrant woman in the US was repeatedly described as a gendered rather than a racialised - experience. Agnes, aged 65, has lived in the US for 42 years. She met her former husband, an American, in Sweden and moved with him to California at the age of 22. She immediately felt at home there: "After seven years in California, you are seen as a native here.” She reflects on her image of married woman in Sweden: “I think Swedish women pamper their husbands. They work like mad. Not only at their jobs, but they work in their homes too.” Agnes prefers American men who "look after women” in a different way than Swedish men. "I find that attractive”, she says.

I thought it was nice that he was tall and strong. You know broad-shouldered. And he seemed to have a plan for life in some way. What he wanted to do. And I felt more like a woman with him. [...] He made sure I had a drink, or somewhere to sit, or that things were arranged for me, or that I was taken care of. And that was attractive. It felt very nice, especially at the beginning of a relationship. You know, when someone looks at you as though you are the most wonderful thing that ever happened to them in their whole life. Swedes are not so good at that. At least not the Swedish men I've come in contact with. Then it's a bit more like, “get your own drink for God's sake. Come on now”. 
Here, race and class are mediated through discourses of gender. It is not the experience of being a white middle-class person - and as such becoming part of white American normativity after a few years - that shapes Agnes' story. Rather, it is the story of 'becoming' a woman and experiencing the contours of womanhood in new and different ways. Agnes feels "more like a woman" in the US because she is looked after and taken care of. This experience was a recurring theme among the Swedish women I interviewed and something that is obviously more important for those married to American men. In Agnes' story, the different behaviour of US men creates a different version of femininity for her to inhabit. This makes Agnes 'feel' more 'woman-like' than she ever did in Sweden. Due to the ideological strivings toward gender equality in Sweden, femininity is perceived as a less valued form of cultural capital than it is in the US, where, according to Agnes, the sexes are regarded as complementary. Agnes adds:

I think it's lovely here, being treated like a woman, in a romantic... to be seen as a woman and not only as a fellow creature. As something special. To be cherished. I think you need that as a woman.

Certainly, in order to be(come) a woman you need to be treated like a woman. For Agnes, this is worth more than equality between women and men, which "erases" the idea of sexual difference that the construction of womanhood rests on. Such an idea relates to a heterosexual matrix where the genders are not only differentiated from each other, but are expected to be attracted to each other (Butler 1990). In her heterosexual encounters with American men, Agnes is able to benefit from her white femininity and shape her social position as a woman in a heterosexual matrix. Although whiteness is not an explicit part of her story, it is possible to read 
whiteness as moving "behind" the Swedish women as they encounter US society. Using the logic of Sara Ahmed, these encounters can be read as inherited proximities, which:

point to how that past that is "behind” our arrival restricts as well as enables human action: if we are shaped by "what" we come into contact with, then we are also shaped by what we inherit, which de-limits the objects that we might come into contact with. (Ahmed, 2007, p. 155)

Such inherited proximities made the women feel welcome, attractive and taken care of (as white heterosexual women). Their Swedish whiteness reinforced their sense of femininity and facilitated new actions that noticeably shaped their entries into the US. These stories were often described as heterosexual encounters. As the Swedish women have "inherited" Nordic purity and beauty, they are well equipped for integration into the upper strata of American life through their contacts with the 'right men'.

\section{Racial purity with "sexual undertones"}

A common theme in the interviews was that Swedes are regarded as "hard working" and "trustworthy" (characteristics that are usually attached to whiteness) in the US. For women, these characteristics are supplemented with beauty, sensuality and sexual liberty - which can be converted into profitable marriages. Alexandra, aged 69, jokingly said that Swedish women “are one of our greatest and finest export commodities”. Alexandra moved to the US 25 years ago and some years later married a very wealthy man. Although now retired, she still volunteers 
in the SWEA network. Alexandra is proud of being Swedish and is particularly proud of the Swedish women she has got to know abroad:

They manage a great part of humanity. Good ladies. Good gene-culture, gene-base. I look at those who have children. Good backbone, good ethics, lucid. We can be proud of all those ladies who give spin to life.

Alexandra clearly locates herself, along with other Swedish women, as racially privileged - or even superior - to other (white and non-white) groups in the world. Her statement is perhaps a mix of the Swedish history of eugenics, in which physical aspects of race form the core of a person's moral characteristics, and the more contemporary ideology of gender equality that foregrounds Swedish women as particularly strong and independent in international comparisons.

An inherent aspect of these narratives is that geographical dislocation forces the women to re-confront aspects of (their) whiteness. As white women in the US they also gained new insights into racial structures and race relations, which made them much more aware of their whiteness, and to some extent, their white privileges. In their stories, the US "melting pot" was contrasted with a (former) Swedish homogeneous and colour-blind society, where issues of race and whiteness are deemed irrelevant in the shadow of a national progressive ideology of anti-racism. In their encounters with a more racially conscious society, the women had become more aware of themselves as white, often for the first time in their lives. In the light of the genealogy of Nordic whiteness in combination with an overt racial hierarchy, the women described themselves as inhabiting a 'whiter' position in the US than in Sweden; a position that is intimately intertwined with gender and class. Those who had travelled from an "ordinary" 
middle-class life to an economically independent life style had become very aware of the capital that had enabled their upward class mobility.

Although the perception of Swedish 'ideal' white femininity and heterosexuality in the US provided space for upward class mobility through heterosexual marriage or employment, this nation-specific version of whiteness also involved being ascribed certain ethno-sexual views of exoticism and sexiness that, to some extent, may jeopardise the women's white middle-class respectability and structural invisibility. Therefore, the women's accounts of contemporary Swedish femininity not only mirror the construction of a certain kind of whiteness, but also a certain kind of sexuality.

When Alice first arrived in the US in the 1970s, she was surprised by the notions of exoticism that were coupled with "Swedish girls". According to her, in the US, Swedish women are regarded as particularly beautiful, but also famous for their sexual liberty. In Alice's view, being "blonde and white” is always appreciated and she has not encountered any racial discrimination - apart from "the sexual undertones” related to her Swedish origin - probably because she "looks American”. Before Alice went to the US she had never thought about her whiteness, "because in Sweden, everybody looks the same”. In the US, her white position has a positive visual impact and is ascribed exotic notions, thereby reflecting the sexualised meanings that are attached to ethnicity (Nagel 2003; Painter 2010); in this case of Swedish women as sexually liberal, beautiful and desirable.

Cornelia, a woman in her eighties who moved from Sweden in the 1950s, points to the good reputation of Sweden, which makes her proud to be Swedish, even though it includes the stereotype of the secular - and sexual - "Swedish girl”.

Catrin: Being Swedish, how do you see that? 
Cornelia: From what I've seen, Swedes have a very good reputation. In every respect. Swedish girls may have been considered a little 'too fast', if you understand what I mean, “Swedish girls are an easy lay”. And maybe we are not as prudish as American girls. We also have very little, we've got no sense of religion at all, you know. So nothing is sinful sex, at least not for my own part ... now. [...] I regard that as a compliment. Now they know that I'm Swedish, and if they don't, I tell them that as soon as I can, because I'm proud of it. Proud may be the wrong word, but I'm happy about it. And of course if they had any reason to criticise Swedes, they would not do it in my presence. But I have heard very little criticism of Sweden. On the contrary. [...] I'm so glad I'm Swedish There was a slogan that said. Hooray, I'm so glad I'm Swedish, or something like that.

Cornelia links the image of the sexual "Swedish girl" to Swedish secularism. The image of sexual liberty is also traced to films such as Summer with Monika released in 1953 (in the US also promoted as Monica: the story of a bad girl) by Ingmar Bergman and inherited by Swedish female figures like Anita Ekberg.

Nevertheless, the notion of the exotic white Swedish woman does not contain the degrading stereotyping aspects of the colonial ethno-sexual mythologies of the Other. As Lunde (2010, 8) puts it, Scandinavians do not trouble the “quintessential and 'ideal' Protestant white fellow from Northern Europe”, "as much as give it a slightly exotic further bleaching of mountain-air chill”. In addition to ethnic traces, Swedish women's sense of being exotic reflects the intersections between unembodied whiteness and embodied femininity, which to some degree could destabilise an unmarked white position yet at the same time provide them with social and material capital. 


\section{Un-marking white privilege}

In their positions as migrants, some of the women expressed mixed feelings about the explicit notions of their Swedish origin. Anna, a single woman in her fifties, moved to the US 30 years ago as a student. She has several male friends, but lives alone with her cat. When Anna tells Americans about her origins they exclaim: “Oh Sweden! But that’s interesting!” "If I had been Mexican it would not have been the same, they would probably have thought that I'd sneaked across the border illegally, didn't have an education, and so on.” Despite her privileged migrant position, Anna prefers not to talk about her Swedish background in social interactions with Americans.

It may stand in the way when you want to get to know people. They only see you as being Swedish. “Okay, Anna, let’s talk about Sweden, what was it like there?” [...] Many Swedes think it is exciting to be that Swedish girl, and have privileges. [...] But I just want to be me.

Anna’s structurally unmarked white position does make space for wanting to belong to - and if not for her dialect, passing as - the US white norm. Not passing as white American locates her in the (non-belonging) position of the migrant (who is expected to talk about her origins). Anna's unwillingness to be associated with "that Swedish girl” and its interrelated qualities is her way of managing the exotic and oversexed notions of her ethnic position (and avoiding thirty years of tiresome questions), because this "symbolic ethnicity" signals excessive femininity and a kind of hyper-sexuality that gets in the way of just being "me” (Waters 1991; 
Nagel 2003). Thus, Swedish "visibility” is not a one-dimensional experience. Although it has helped the women to climb the class-ladder and have white American privileges, it has also left some of them feeling 'too gendered'.

This is perhaps where the construction of whiteness and white identity as “structurally invisible” is most obvious (Frankenberg 1993). In order to become eligible as an individual - "me" - it is necessary to avoid explicit privileges tied to whiteness and to manage the ascribed notions of embodied Swedish femininity. Here, the contrary constructions of whiteness and gender become perceptible for the women, since the former is defined as an unmarked position and the latter as an embodied experience. As white Swedish migrant women they have to balance the tension between marked and unmarked (gendered) whiteness by investing their white femininity in a respectable project, where they can pass as (white) American (women) and thereby avoid being compromised by the haunting image of the Swedish, blonde, liberated, hyper-sexualised woman. In this light, Anna reflects on her desire to be an (class, race and gender-neutral) individual, rather than being part of a particularly privileged (white) group or exoticised as a Swedish migrant woman.

\section{Conclusion}

The Swedish migrant women's narratives reveal gender- and nation-specific dimensions of whiteness in the US, thereby illuminating how transnational racial hierarchies and complexities are activated by white European migrants as they are incorporated into a social structure that continues to privilege people of (northwest) European and Nordic origin. In their stories, ideological and symbolic constructions of femininity, whiteness and Swedishness intersect with dominant western ideals of beauty, such as blonde hair and blue eyes. These racial privileges are mainly shaped, transformed and/or reproduced by their capacity to re-invest their cultural 
and embodied forms of Swedishness as white capital. In this conversion of capital, gender and whiteness intersect in somewhat diverse and sometimes conflicting ways, where gender can get in the way of an individually unmarked and structurally invisible white position. As Swedish migrant women, they have to re-negotiate gender and whiteness in relation to national and transnational relations, which involves balancing exoticism and respectability in new ways.

Their accentuated whiteness implies re-configurations of femininity and respectability, and vice versa. As symbolic bearers of the racialised boundaries of the Swedish nation and its 'national qualities', the women are ascribed a particular notion of whiteness, namely a Swedish (or Nordic) hyper-whiteness. This is coupled with standards of homogeneity and extraordinary beauty, including certain ethno-sexual notions of exoticism and a dubious sexual morality that destabilises their white middle-class respectability and structural invisibility. In both cases, whiteness functions as an orientation "behind" the category of gender that also provides them with a form of white capital and a local exchange value that can be converted into a profitable marriage.

As white privileges are usually normalised and are invisible and unproblematic to the subjects that embody them, a transnational intersectional perspective can help us to understand how gender, nationality, sexuality and class 'mark' whiteness in new and shifting ways. For the women in this study, reinstalling whiteness in a different national racial system prompted feelings of increased opportunities in life, but also evoked a sense of being deprived of their normative and structurally invisible position. In this sense, re-locating whiteness can create new insights into how white subjects themselves experience whiteness. It can also lead to insights into how whiteness, as a transnational construct, changes as it becomes contextualised in diverse racial settings - in this case from unmarked colour-blind white normativity to an overt and distinct form of gendered white privilege. 


\section{References}

Ahmed, Sara. 2000. Strange encounters: Embodied Others in post-coloniality. London: Routledge.

Ahmed, Sara. 2007. ”The phenomenology of whiteness.” Feminist Theory, 8: 149-168.

Beijbom, Ulf. 2006. Utvandrarkvinnor. Svenska kvinnoöden i Amerika [Migrant Women: Swedish women’s life stories in America]. Stockholm: Norstedts.

Blanck, Dag. 2006. The creation of an ethnic identity: being Swedish American in the Augustana Synod, 1860-1917. Carbondale: Southern Illinois University Press.

Brigham, Carl Campbell. 1923. A study of American Intelligence. Princeton: Princeton University Press.

Borchorst, Anette and Birte Siim. 2008. "Woman-friendly policies and state feminism: Theorizing Scandinavian gender equality.” Feminist Theory, 9 (2): 207- 224.

Bourdieu, Pierre. 1986. “The Forms of Capital.” In Handbook of Theory and Research for the Sociology of Education, edited by Richardson John G, 241-258. New York: Greenwordpress.

Butler, Judith. 1990. Gender trouble: feminism and the subversion of identity. New York: Routledge.

Dyer, Richard. 1997. White: essays on race and culture. London: Routledge.

Eriksson, Anette. 2008. Svenskar i världen [Swedes in the World]. Välfärd, 1: 6-7.

Frankenberg, Ruth. 1993. White women, race matters. The social construction of Whiteness. Minneapolis: University of Minnesota Press.

Fur, Gunlög. 2006. Colonialism in the Margins: Cultural Encounters in New Sweden and Lapland. Leiden and Boston: Brill Academic Publishers.

Garner, Steve. 2007. Whiteness: an introduction. New York: Routledge.

Garner, Steve. 2015. A moral economy of whiteness: four frames of racializing discourse. Abingdon: Routledge. 
Gustafsson Chorell, Torbjörn. 1996. Själens biologi. Medicinen, kulturen och naturens ordning 1850-1920 [The biology of the soul. Medicine, culture and the order of nature 1850-1920]. Eslöv: Brutus Östlings Bokförlag Symposion.

Hirdman, Yvonne. 1989. Att lägga livet till rätta [Putting life in order]. Stockholm: Carlsson. Hübinette, Tobias, and Catrin Lundström. 2014 "Swedish whiteness and white melancholia: A case study of a white nation in crisis and its history and future”. In Unveiling whiteness in the 21st century: Global manifestations, transdisciplinary interventions, edited by Veronica Watson, Deirdre Howard-Wagner, and Lisa Spanierman, 49-74. Lanham: Lexington Books. Johannisson, Karin. 1991. ’Folkhälsa. Det svenska projektet från 1900 till 2:a världskriget [Publichealth. The Swedish project from 1900 to World War II].” Lychnos 54: 139-195.

Johnson, Allan G. 2001. Power, privilege, and difference. Mountain View: Mayfield.

Keskinen, Suvi et al, ed. 2009. Complying with colonialism: gender, race and ethnicity in the Nordic region. Aldershot: Ashgate

Kimmel, Michael. 2003. “Introduction. Toward a Pedagogy of the Oppressor.” In Privilege: a reader, edited by Michael Kimmel, and Abby L. Ferber, 1-14. Boulder: Westview Press.

Lan, Pei-Chia. 2011. "White Privilege, Language Capital and Cultural Ghettoisation: Western High-Skilled Migrants in Taiwan.” Journal of Ethnic and Migration Studies, 37 (10): 16691693.

Lindvert, Jessica. 2002. Feminism som politik. Sverige och Australien 1960-1990 [Feminism as Politics: Sweden and Australia 1960-1990]. Umeå: Boréa.

Lintelman, Joy K. 1991. ”'Our Serving Sisters': Swedish-American Domestic Servants and Their Ethnic Community.” Social Science History, 15 (3): 381-95.

Lunde, Arne. 2010. Nordic exposures: Scandinavian identities in classical Hollywood cinema. Seattle: University of Washington Press. 
Loftsdóttir, Kristín and Lars Jensen. 2012. Whiteness and postcolonialism in the Nordic Region: exceptionalism, migrant others and national identities. Farnham: Ashgate.

Lundström, Catrin. 2010. "White ethnography: (un)comfortable conveniences and shared privileges in field-work with Swedish migrant women.” Nora 18 (2):70-87.

Lundström, Catrin. 2014. White Migrations: Gender, Whiteness and Privilege in Transnational Migration. Basingstoke: Palgrave Macmillan.

Matović, Margareta. 1997. “Embracing a middle-class life: Swedish-American women in Lake View.” In Peasant maids - city women from the European countryside to urban America, edited by Christiane Harzig, 261-297. New York: Cornell University Press.

McIntosh, Peggy. 2003. "White Privilege and Male Privilege: A personal account of coming to see correspondences through work in women's studies.” In Privilege: a reader, edited by Michael Kimmel, and Abby L. Ferber, 3-25. Boulder: Westview Press.

Moon, Dreama. 1999. "White Enculturation and Bourgeois Ideology. The Discursive Production of 'Good (White) Girls'”. In Whiteness. The Communication of Social Identity edited by Thomas Nakayama and Judith Martin, 177-199. Thousand Oaks: Sage.

Moreton-Robinson, Aileen, Maryrose Casey, and Fiona Nicoll, ed. 2008. Transnational whiteness matters. Lanham: Lexington Books.

Nagel, Joane. 2003. Race, Ethnicity and Sexuality: Intimate Intersections, Forbidden Frontiers. New York and Oxford: Oxford University Press.

Painter, Nell Irvin. 2010. The History of White People. New York \& London: W. W. Norton \& Company.

Pease, Bob. 2010. Undoing privilege: unearned advantage in a divided world. London: Zed.

Roediger, David R. 1991. The wages of whiteness: race and the making of the American working class. London: Verso. 
Shome, Raka. 2011. "'Global Motherhood': The Transnational Intimacies of White Femininity.\# Critical Studies in Media Communication, 28 (5): 388-406.

Skeggs, Beverley. 1997. Formations of Class and Gender: Becoming Respectable. London: Sage.

Skeggs, Beverley. 2004. Class, Self, Culture. London: Routledge.

Twine, France Winddance. 2010. A white side of black Britain. Durham: Duke University Press.

Wallengreen, Anna-Karin. 2013. Välkommen hem Mr Swanson: svenska emigranter och svenskhet på film [Welcome home Mr Swanson: Swedish migrants and Swedishness on film]. Lund: Nordic Academic Press.

Waters, Mary C. 1990. Ethnic options: choosing identities in America. Berkeley: University of California Press.

Weiss, Anja. 2005. “The Transnationalization of Social Inequality. Conceptualizing Social Positions on a World Scale.” Current Sociology, 53: 707-724.

\section{Acknowledgements}

I am deeply grateful to the women who shared their experiences with me. In the writing process, I would like to thank the two anonymous reviewers for their insightful and helpful comments, and Ben Teitelbaum for our discussions about Nordic whiteness. This research was supported by The Swedish Council for Working Life and Social Research (FAS) and The SwedenAmerica Foundation/American-Scandinavian Foundation (ASF). 


\section{Footnotes}

${ }^{1}$ All the names in the article have been changed to ensure the informants' anonymity. For a complete methodological discussion, see Lundström (2010).

${ }^{2}$ In her discussion about white mothers of mixed-race children, Twine (2010) uses the concept of 'ethnic capital' to refer to a set of cultural knowledge that the women draw from in their communities. I use white capital to discuss the resources that the women carry with them in terms of white cultural capital.

${ }^{3}$ About half of the women in the US sample have an upper-class background, in a Swedish national social class context indicated by belonging to a noble or ennobled family with surnames prefixed by "af” or “von”.

${ }^{4}$ Sweden has a colonial relation to the US as well. Between 1638 and 1654, the colonies known as New Sweden in the States of Delaware, New Jersey, Pennsylvania and Maryland belonged to Sweden, although these were later 'lost' to the Netherlands. See Fur (2006) for a discussion about Swedish settlers and indigenous people.

${ }^{5}$ The Swedish maid was so common at the time that she became a fictional figure in a series of comedy films about “Sweedie” between 1914 and 1916, played by the male actor Wallace Beery (see Matović 1997; Wallengreen 2013). 